\title{
Influence of glyceryl guaiacolate ether on anesthetics in tilapia compared to benzocaine and eugenol
}

\author{
Influencia del eter gliceril guayacolato sobre la anestesia en \\ tilapias comparado con benzocaina y eugenol
}

\author{
Geovana R. Cosenza, ${ }^{1}$ MV, Gustavo S. Claudiano, ${ }^{1,2}$ M.Sc, Paulo F. Marcusso, ${ }^{1,2}$ M.Sc, \\ Silas F. Eto, ${ }^{1,2}$ M.Sc, Wilson G. Manrique, ${ }^{1}$ Ph.D, Bruna A. Loureiro, ${ }^{3}$ M.Sc, \\ Marina T. Shimada, ${ }^{1}$ M.Sc, Rogerio Salvador, ${ }^{1,2}$ Ph.D, Julieta RE. Moraes, ${ }^{1}$ Ph.D, \\ Flavio R. Moraes, ${ }^{1,2 *}$ Ph.D.
}

\begin{abstract}
${ }^{1}$ Universidade Estadual Paulista, Departamento de Patologia Veterinaria, Via Prof. Paulo Donato Castellane km 05, CEP 14.884-900, Jaboticabal, Sao Paulo, Brazil. '2Universidade Estadual do Norte do Parana, Laboratorio de Imunopatologia de Peixes, Rodovia BR-369 Km 54,Vila Maria, CP 261,CEP 86360-000, Bandeirantes, Parana, Brazil. ${ }^{3}$ Universidade Estadual Paulista, Departamento de Zootecnia, Via Prof. Paulo Donato Castellane km 05, CEP 14.884-900, Jaboticabal, Sao Paulo, Brazil. *Correspondence: fruasmoraes@gmail.com
\end{abstract}

Received: March 2013; Accepted: September 2013.

\begin{abstract}
Objective. The study aimed to investigate the effectiveness of glyceryl guaiacolate ether (GGE) and compare the times of induction, recovery, hematological changes, total protein and glycaemia among anesthetics in Nile tilapia, Oreochromis niloticus. Materials and methods. A total of 60 tilapia distributed in 3 aquariums $(\mathrm{N}=20)$ were used, which formed the group benzocaine $(100 \mathrm{mg} / \mathrm{L})$, eugenol $(50 \mathrm{mg} / \mathrm{L})$ and guaiacol glyceryl ether $(9.000 \mathrm{mg} / \mathrm{L})$. After the induction of anesthesia fish blood samples were collected to determine the complete hemogram and glycemia. Then the animals were placed in aquariums with running water for assessing the anesthesia recovery. Results. It was verified that GGE showed longer induction and recovery times as well a significant increase $(p<0.05)$ of glycemia, when compared with the other groups $(p<0.05)$. The concentration of total protein did not differ between groups $(p>0.05)$. An increase in the number of monocytes in the group treated with benzocaine $(p<0.05)$ was observed in the analysis of the hematological parameters with no difference between groups for other variables. Conclusions. Eugenol and benzocaine allow rapid induction and recovery in Nile tilapia, without evidence of stress during handling and GGE showed high induction and recovery times, being inadequate for anesthetic use in Nile tilapia.
\end{abstract}

Key words: Anesthesia, hemogram, teleosts, Oreochromis niloticus (Source: $C A B$ ).

\section{RESUMEN}

Objetivo. El trabajo tuvo como objetivo investigar la eficacia del eter gliceril guayacolato (EGG) y comparar los tiempos de inducción, recuperación, alteraciones hematológicas, de proteínas totales y glicemia entre los anestésicos en tilapias del Nilo, Oreochromis niloticus. Materiales y métodos. Fueron utilizadas 60 tilapias distribuidas en 3 acuarios $(n=20)$, que formaron los grupos benzocaína $(100 \mathrm{mg} / \mathrm{L})$, eugenol $(50 \mathrm{mg} / \mathrm{L})$ y éter gliceril guayacolato $(9.000 \mathrm{mg} / \mathrm{L})$. Después de la inducción 
anestésica se procedió a colectar la sangre para determinar el hemograma y glicemia. A seguir, los animales fueron colocados en acuarios con agua corriente para la evaluación de la recuperación anestésica. Resultados. Se verificó que el EGG presentó mayor tiempo de inducción y recuperación, así como aumento significativo $(p<0.05)$ de la glicemia, cuando fue comparado con los otros grupos $(p<0.05)$. La concentración de las proteínas totales no fueron diferentes entre los grupos $(p>0.05)$. En el análisis de los parámetros hematológicos fue observado aumento del número de monocitos en el grupo tratado con benzocaína $(p<0.05)$ sin diferencia ente los grupos para las otras variables. Conclusiones. El eugenol y la benzocaína permiten rápidas inducciones y recuperación en tilapias del Nilo, sin evidencias de estrés durante la manipulación y el EGG presenta tiempos elevados de inducción y recuperación, no siendo este adecuado para el uso en tilapias del Nilo.

Palabras clave: Anestesia, hemograma, teleósteos, Oreochromis niloticus (Fuente: CAB).

\section{INTRODUCCIÓN}

La expansión e intensificación de la piscicultura genera problemas de manejo y sanidad, pues el aumento de la densidad produce pérdida de la calidad del agua, condiciones adversas de manejo y otras que resultan en estrés con depresión de los mecanismos de defensa (1).

Dentro de este contexto, la utilización de los anestésicos en peces es ampliamente empleada para disminuir los efectos adversos del manejo como forma de garantizar la integridad de los animales, así como reducir la mortalidad y facilitar su manipulación (2). Entre los anestésicos más utilizados en peces se encuentra la tricaína metanosulfonato (MS222), benzocaína, quinaldina, 2-fenoxietanol, aceite de clavo y sus derivados (eugenol, metileugenol e isoeugenol) (2).

En Brasil no existen leyes que regulen el uso de anestésicos en peces, adaptando así, recomendaciones de la Food and Drugs Administration (FDA). De esta forma, se buscan alternativas de anestésicos más seguros y eficaces para uso en la piscicultura. El efecto de diferentes anestésicos sobre los parámetros fisiológicos de los peces es variado con relación a los diferentes anestésicos y especies utilizadas.

La benzocaína actúa bloqueando los canales de sodio y reduce los potenciales de acción de la membrana celular (3). Dependiendo del grado pretendido de depresión del pez, está indicada la adición de solución de benzocaína con etanol o acetona en el agua en dosis de 25 a $100 \mathrm{mg} / \mathrm{L}$. Por esta razón, peces sometidos a anestesia con benzocaína y destinados para alimentación, deben ser sometidos a cuarentena (4).

El "aceite de clavo" es un compuesto fenólico resultante de la destilación de las hojas y flores de los árboles de clavo de la India (Syzgium aromaticum), siendo el eugenol su sustancia

\section{INTRODUCTION}

The expansion and intensification of fish farming creates handling and health problems, because an increase in density leads to a loss in water quality, adverse handling conditions and others that result in stress with a decrease in defense mechanisms (1).

Within this context, the use of anesthetics in fish is widely used to reduce the adverse effects in handling as a way to ensure the integrity of animals, as well as reduce mortality and facilitate manipulation (2). The anesthetics mostly used in fish include the tricaine methanesulfonate (MS222), benzocaine, quinaldine, 2-phenoxyethanol, clove oil and its derivatives (methyleugenol, eugenol and isoeugenol) (2).

In Brazil there are no laws that regulate the use of anesthetics in fish, so the recommendations of the Food and Drugs Administration (FDA) have been adapted. In this way, alternatives are being sought for having safer and more effective anesthetics for use in fish farming. The effect of different anesthesia on the physiological parameters of fish is varied in relation to the different anesthetics and species used.

Benzocaine acts by blocking sodium channels and reduces the action potential of cell membranes (3). Depending on the intended degree of depression in the fish, the addition of a solution of benzocaine with ethanol or acetone in water at a dose of 25 to $100 \mathrm{mg} / \mathrm{L}$ is indicated. For this reason, fish under anesthesia with benzocaine and intended for feeding must be subjected to quarantine (4).

Clove oil is a phenolic compound resulting from the distillation of leaves and flowers of the clove trees in India (Syzgium aromaticum), with eugenol being its active ingredient, ranging from $70 \%$ to $95 \%$ (5). It is listed as a safe, 
activa, variando entre 70 y $95 \%$ (5). Este es catalogado como anestésico seguro, eficaz, de bajo costo y con amplio margen de seguridad para peces, además de ser atóxico para el operador en las dosis mencionadas. Otra ventaja de este compuesto es que su metabolización y excreción son rápidas, permitiendo el consumo sin esperar un período de cuarentena (6). La Food and Agriculture Organization (FAO) prescribe como aceptable la ingestión diaria de $2.5 \mathrm{mg}$ eugenol $/ \mathrm{kg}$ en seres humanos. En peces anestesiados con $450 \mathrm{mg} / \mathrm{L}$ de aceite de clavo demostró que después de 48 horas antes del abate, hubo retención de apenas $0.32 \mathrm{mg}$ de eugenol $/ \mathrm{kg}$, valor que está dentro de los niveles aceptables para la FAO (7).

El éter gliceril guayacol (EGG) o guaifenesina es un polvo blanco, de sabor amargo, poco soluble en agua. Es relajante muscular de acción central que bloquea reflejos polisinápticos y deprime la transmisión de impulsos nerviosos en las neuronas intercelares de la médula espinal, utilizado ampliamente en equinos (8). Aunque este compuesto esté asociado al relajamiento muscular con sedación y efecto analgésico mínimo, sus efectos en peces todavía no fueron evaluados.

El objetivo del presente estudio fue evaluar el tiempo de inducción y recuperación así como determinar la glicemia, concentración de proteínas totales y las variables hematológicas en tilápias del Nilo, Oreochromis niloticus, sometidas a los efectos anestésicos de benzocaína, eugenol y éter gliceril guayacol con el propósito de evaluar este último para uso en la manipulación de peces en procedimientos de rutina.

\section{MATERIALES Y MÉTODOS}

Sitio de estudio. El experimento fue realizado en la Universidade Estadual do Norte do Paraná, Campus Luiz Meneghel, en Bandeirantes, Paraná

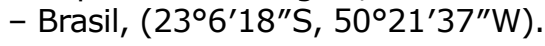

Animales y acondicionamiento. Fueron utilizadas 60 tilápias del Nilo, Oreochromis niloticus con peso medio de $95.0 \pm 1.5 \mathrm{~g}$ distribuidos en 3 acuarios con capacidad de $350 \mathrm{~L}(\mathrm{n}=20)$, abastecidos con agua de pozo artesanal, con flujo de agua $1 \mathrm{~L} / \mathrm{min}$ y aireación artificial. La calidad del agua fue monitoreada diariamente y los peces alimentados dos veces al día (9:00 y $17: 00 \mathrm{~h}$ ) con concentrado comercial para peces $20 \%$ de proteína bruta, con ofrecimiento de $3 \%$ de la biomasa.

Protocolo experimental. Los peces fueron divididos en tres grupos $(n=20)$ en un delineamiento enteramente al azar. Todos los peces fueron sometidos a anestesia por el método de inmersión, effective, affordable anesthetic with a wide safety margin for fish, as well as being non-toxic for the operator in the doses mentioned. Another advantage of this compound is that metabolism and excretion are faster, allowing consumption without waiting for a quarantine period (6). The Food and Agriculture Organization (FAO) indicates as acceptable a daily intake of $2.5 \mathrm{mg}$ eugenol/ $\mathrm{kg}$ in humans. In fish anesthetized with $450 \mathrm{mg} / \mathrm{L}$ of clove oil, it was demonstrated that after 48 hours prior to abate there was a retention of just $0.32 \mathrm{mg}$ of eugenol $/ \mathrm{kg}$, a value that is within the acceptable levels for the FAO (7).

Guaiacol glyceryl ether (GGE) or guaifenesin is a white powder, with a bitter taste, little soluble in water. It is a muscle relaxant of central action that blocks polysynaptic reflexes and depresses the transmission of nerve impulses in spinal cord neurons, widely used in horses (8). Although this compound is associated with muscle relaxation through sedation and a minimal analgesic effect, its effects on fish are yet to be evaluated.

The objective of this study was to assess the time of induction and recovery as well as determine glycemia, total protein concentration and hematological variables in Nile tilapias, Oreochromis niloticus, subjected to the anesthetic effects of benzocaine, eugenol, and guaiacol glyceryl ether in order to assess the latter for use in fish manipulation in routine procedures.

\section{MATERIALS AND METHODS}

Study site. The experiment was conducted in Universidade Estadual do Norte do Parana, Campus Luiz Meneghel, in Bandeirantes,

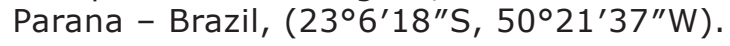

Animals and conditioning. Sixty Nile tilapias, Oreochromis niloticus, were used with an average weight of $95.0 \pm 1.5 \mathrm{~g}$ distributed in 3 aquariums with a capacity of $350 L(n=20)$, supplied with water from a well, a water flow of $1 \mathrm{~L} / \mathrm{min}$ and artificial aeration. Water quality was monitored daily and fish fed twice a day (9:00 and 17:00 h) with commercial fish concentrated with $20 \%$ of crude protein, with a biomass offer of $3 \%$.

Experimental protocol. Fish were divided into three groups $(n=20)$ in an entirely random outline. All the fish were subjected to anesthesia through the immersion method, each prepared with different concentrations. Benzocaine (BEN) was diluted in ethanol $(0.1 \mathrm{~g} / \mathrm{ml})$ and in water for 
cada uno preparada en concentraciones diferentes. La benzocaína (BEN) fue diluida en alcohol etílico $(0.1 \mathrm{~g} / \mathrm{ml})$ y esta en agua para concentración final de 100 mg/L (9). El eugenol (EUG) y gliceril éter guayacolato (EGG) se diluyeron directamente en el agua a una concentración de 50 mg/L (10) y 9.000 $\mathrm{mg} / \mathrm{L}$ (dosis establecida en las pruebas anteriores), respectivamente. Para el ensayo, cada pez fue capturado con nasa al azar y colocado en recipientes plásticos con volumen útil de $50 \mathrm{~L}$, donde los peces fueron mantenidos hasta el estado IV (Tabla 1).

Table 1. Stages of anesthesia according to Ross y Ross (11).

\begin{tabular}{|c|c|c|}
\hline State & Description & Behavioral response in fish \\
\hline 0 & Normal & $\begin{array}{l}\text { Reaction to external stimuli, normal opercular } \\
\text { movements, normal muscular reaction. }\end{array}$ \\
\hline I & Mild sedation & $\begin{array}{l}\text { Reaction to external stimuli, slow swimming } \\
\text { movements, small opercular movements, } \\
\text { normal balance. }\end{array}$ \\
\hline II & $\begin{array}{l}\text { Deep } \\
\text { sedation }\end{array}$ & $\begin{array}{l}\text { Total loss to external stimuli, even to strong } \\
\text { pressure, reduced opercular movements. }\end{array}$ \\
\hline III & Narcosis & $\begin{array}{l}\text { Partial loss of muscle tone, erratic swimming, } \\
\text { increased opercular movements, reaction to } \\
\text { tactile stimuli and vibration. }\end{array}$ \\
\hline IV & $\begin{array}{l}\text { Deep } \\
\text { anesthesia }\end{array}$ & $\begin{array}{l}\text { Total loss of muscle tone, balance, slow but } \\
\text { constant opercular movements. }\end{array}$ \\
\hline V & $\begin{array}{l}\text { Surgical } \\
\text { anesthesia }\end{array}$ & $\begin{array}{l}\text { Total absence of reaction, slow and irregular } \\
\text { opercular movements, decreased heart rate, } \\
\text { and complete loss of all reflexes. }\end{array}$ \\
\hline VI & $\begin{array}{l}\text { Spinal } \\
\text { collapse }\end{array}$ & Decreased heart rate and total loss of reflexes. \\
\hline
\end{tabular}

Parámetros hematológicos. Después de la inducción se realizó la colecta de aproximadamente $2 \mathrm{~mL}$ de sangre de cada pez, por medio de la venopunción caudal. A partir de esas muestras fueron determinados la glicemia (Accu-Check ${ }^{\circledR}$ Active-Roche), porcentual de hematocrito (12), concentración de proteínas plasmáticas totales por el método biureto (545 $\mathrm{nm}$ de longitud de onda), la tasa de hemoglobina y el recuento de eritrocitos en cámara de Neubauer (13). Una vez fueron determinados estos datos, fueron calculados los índices hematimétricos comprendidos por el volumen corpuscular medio (VCM), hemoglobina corpuscular media (HCM) y concentración de la hemoglobina corpuscular media (CHCM). Para el recuento de leucocitos totales se utilizó la cámara de Neubauer siguiendo los procedimientos descritos por Martins et al (14) y tinciones según Tavares-Dias \& Moraes (15).

Tiempos de exposición a los anestésicos. Para evaluar la recuperación anestésica los peces fueron colocados en acuarios con $90 \mathrm{~L}$ de agua corriente, con flujo de $1 \mathrm{~L} / \mathrm{min}$. Durante este periodo fueron observadas las variables descritas por Grush et al (16) donde: i) reaparecimiento de movimientos operculares, ii) retorno parcial del equilibrio y de la capacidad de nado, iii) recuperación total del equilibrio, iv) nado y reacción para estímulos externos todavía vacilantes y v) recuperación total a final concentration of $100 \mathrm{mg} / \mathrm{L}$ (9). Eugenol (EUG) and guaiacolate glyceryl ether (GGE) were diluted directly in water at a concentration of $50 \mathrm{mg} / \mathrm{L}$ (10) and $9.000 \mathrm{mg} / \mathrm{L}$ (dose established in previous tests), respectively. For the assay, each fish was captured with a creel at random and placed in plastic containers with a volume of $50 \mathrm{~L}$, where fish were maintained until state IV (Table 1).

Hematological parameters. Approximately $2 \mathrm{~mL}$ of blood were collected from each fish after the induction, by means of the caudal venipuncture. These samples served to determine the glycemia (Accu-Check ${ }^{\circledR}$ ActiveRoche), hematocrit percentage (12), total plasma protein concentration by the biuret method (545 nm wavelength), hemoglobin rate and erythrocytes count in a Neubauer chamber (13). Once these data were determined, the hematimetric indexes, composed of the mean corpuscular volume (MCV), mean corpuscular hemoglobin $(\mathrm{MCH})$ and mean corpuscular hemoglobin concentration (MCHC), were calculated. Total leukocytes were counted through the Neubauer chamber following the procedures described by Martins et al (14) and stains according to Tavares-Dias \& Moraes (15).

Exposure times to anesthetics. To evaluate the anesthetic recovery, the fish were placed in aquariums with $90 \mathrm{~L}$ of tap water, with a flow of $1 \mathrm{~L} / \mathrm{min}$. During this period were observed the variables described by Grush et al (16) where: i) reemergence of opercular movements, ii) partial return of balance and swimming ability, iii) total recovery of balance, iv) swimming ability and reaction to external stimuli still unsteady, and v) total balance recovery and normal swimming ability. The times required for induction and anesthetic recovery were evaluated with a digital stopwatch. During the exposure period the animals were evaluated by direct observation for signs of intoxication, taking into account the alterations of behavior and mortality.

Statistics. The results were subjected to analysis of variance and comparison of means by the Tukey test with five percent significance $(p<0.05)(17)$.

\section{RESULTS}

The quality of water remained within the comfort values of the fish $\left(D O=5.1 \mathrm{mg} / \mathrm{L}: \mathrm{T}_{0}=26.47^{\circ} \mathrm{C}\right.$; $\mathrm{pH}=7.66$ and electrical conductivity $=117.96 \mu \mathrm{S} / \mathrm{cm}$ ) (18). The three substances used as anesthetics in Nile tilapia were able to annul the reactions to handling and material collection, including fish out of the 
del equilibrio y capacidad normal de nado. Los tiempos requeridos para inducción y recuperación anestésica fueron evaluados en cronómetro digital. Durante el período de exposición los animales fueron evaluados por observación directa en busca de señales de intoxicación, teniendo en cuenta las alteraciones de comportamiento y mortalidad.

Estadística. Los resultados fueron sometidos a análisis de varianza y la comparación de medias por la prueba de Tukey cinco por ciento de significación $(p<0.05)(17)$.

\section{RESULTADOS}

La calidad del agua permaneció dentro los valores de confort de los peces ( $O D=5.1$ $\mathrm{mg} / \mathrm{L}: \mathrm{T}_{0}=26.47^{\circ} \mathrm{C} ; \mathrm{pH}=7.66$ y conductividad eléctrica $=117.96 \mu \mathrm{S} / \mathrm{cm})(18)$. Las tres sustancias utilizadas como anestésicos en tilápias del Nilo fueron capaces de abolir las reacciones a la manipulación y a la colecta de material, inclusive con los peces fuera del agua. Sin embargo, hubo diferencias en la inducción y recuperación y en la glicemia determinada después de la inducción anestésica.

Con relación a la inducción los animales del grupo EGG presentaron un tiempo mayor $(p<0.05)$ a los observados en los grupos BEN e EUG (Figura 1). Los tiempos medios de inducción

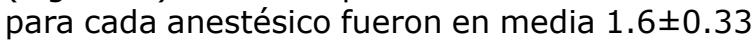
minutos para el grupo EUG; $2.58 \pm 0.51$ minutos para el grupo BEN y $10.88 \pm 2.09$ minutos para el grupo EGG; demostrando que las dosis preseleccionadas de cada compuesto fueron eficientes para la inducción anestésica y la manipulación, incluyendo la venopunción, sin reacción en los animales.

Lo mismo puede ser observado con relación a los tiempos de recuperación en el grupo EGG con tiempo medio de $37.54 \pm 30.49$ minutos para la recuperación de los peces, fue mayor $(p<0.05)$ a los grupos BEN y EUG, con tiempos de $3.88 \pm 0.89$ y $2.38 \pm 1.25$ minutos, respectivamente (Figura 2 ).

En el grupo anestesiado con EGG la tasa de glicemia fue superior $(p<0.05)$, (Figura 3 ) a los grupos BEN y EUG. En el análisis de los parámetros hematológicos (Tabla 2), las sustancias ensayadas no difieren $(p>0.05)$ en relación a la concentración de las proteínas plasmáticas totales. Entre tanto, se observó que el EGG disminuyó significativamente $(p<0.05)$ los valores de los monocitos circulantes con relación a los otros anestésicos (Tabla 2). water. However, there were differences in the induction and recovery and glycemia determined after anesthetic induction.

With respect to induction, animals in the GGE group showed times $(p<0.05)$ higher than those observed in the groups BEN and EUG (Figure 1). The mean induction times for each anesthetic were on average $1.6 \pm 0.33$ minutes for group EUG; $2.58 \pm 0.51$ minutes for group BEN and 10.88 \pm 2.09 minutes for group GGE; demonstrating that the preselected dose of each compound was efficient for anesthetic induction and manipulation, including venipuncture, with no reaction in the animals.

The same can be observed with regard to recovery times in the GGE group with an average time of $37.54 \pm 30.49$ minutes for the recovery

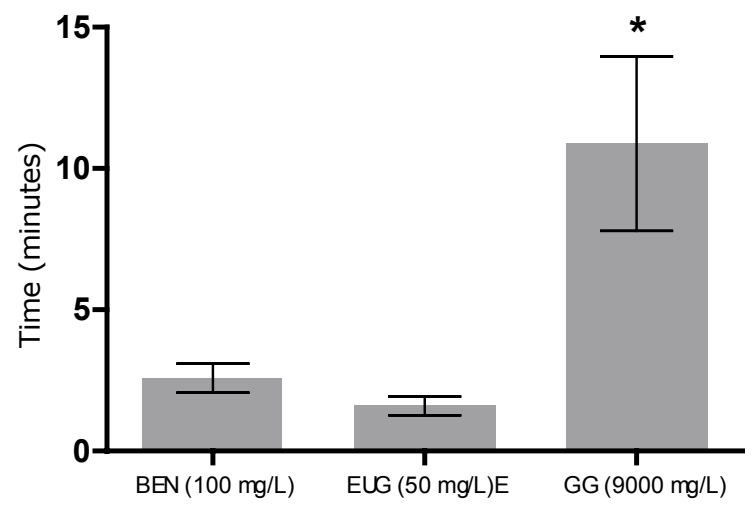

Figure 1. Anesthetic effect at the time of anesthetic induction in Nile tilapia exposed to benzocaine (BEN), eugenol (EUG) and guaiacol glyceryl ether (GGE). Results are expressed as mean \pm standard error $(\mathrm{N}=20)$ *significant difference with Tukey test $(p<0.05)$.

of fish, which was higher $(p<0.05)$ than the BEN and EUG groups, with times of $3.88 \pm 0.89$ and $2.38 \pm 1.25$ minutes, respectively (Figure 2 ).

In the group anesthetized with GGE the glycemia rate was higher $(p<0.05)$ (Figure 3 ) than the BEN and EUG groups. In the analysis of hematological parameters (Table 2), the substances tested did not differ $(p>0.05)$ in relation to the total plasma protein concentration. Meanwhile, it was observed that the GGE significantly decreased $(p<0.05)$ the values of circulating monocytes in relation to other anesthetics (Table 2 ). 


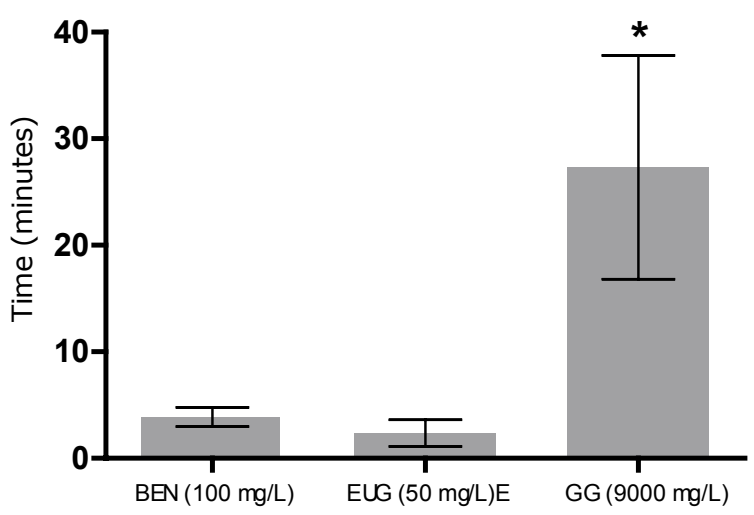

Figure 2. Effect of anesthetics in the recovery time of Nile tilapia exposed to benzocaine (BEN), eugenol (EUG) and guaiacol glyceryl ether (GGE). Results are expressed as mean \pm standard error $(\mathrm{N}=20) *$ significant difference with Tukey test $(p<0.05)$.

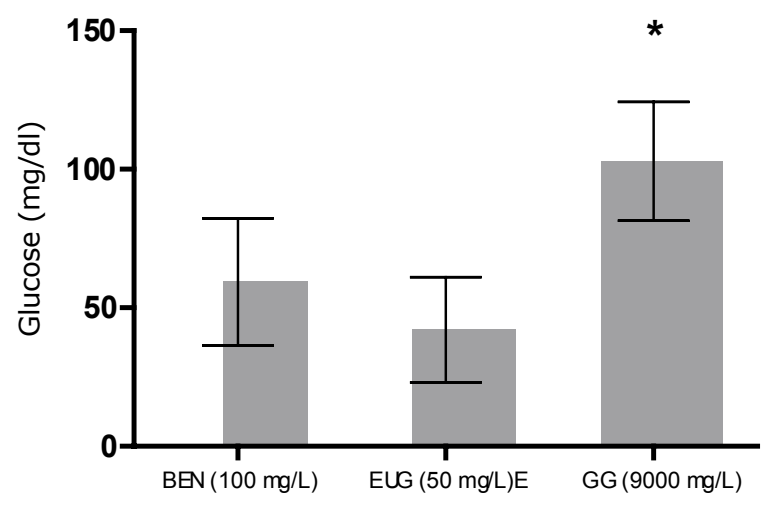

Figure 3. Effect of treatment with benzocaine (BEN), eugenol (EUG) and guaiacol glyceryl ether (GGE) in blood glucose levels in Nile tilapia. Results are expressed as mean \pm standard error $(N=20) *$ significant difference with Tukey test $(p<0.05)$.

Table 2. Average values (standard error) and analysis of variance of hematological variables of Oreochromis niloticus under BEN, EUG and GGE anesthetics.

\begin{tabular}{|c|c|c|c|}
\hline \multirow{2}{*}{ Variables } & \multicolumn{3}{|c|}{ Anesthetics } \\
\hline & BEN & EUG & GGE \\
\hline VG (\%) & $27.2 \pm 2.1^{\mathrm{a}}$ & $32.2 \pm 2.4^{\mathrm{a}}$ & $30.2 \pm 2.6^{\mathrm{a}}$ \\
\hline Ert $\left(\times 10^{6} / \mathrm{mm}^{3}\right)$ & $1.7 \pm 0.2^{\mathrm{a}}$ & $1.6 \pm 0.3^{\mathrm{a}}$ & $1.8 \pm 0.2^{\mathrm{a}}$ \\
\hline $\mathrm{Hb}(\mathrm{g} / \mathrm{dL})$ & $5.8 \pm 0.4^{\mathrm{a}}$ & $6.2 \pm 0.7^{a}$ & $5.3 \pm 0.2^{\mathrm{a}}$ \\
\hline VCM (fL) & $170.3 \pm 26.2^{\mathrm{a}}$ & $182.1 \pm 30.2^{\mathrm{a}}$ & $201.3 \pm 17.8^{\mathrm{a}}$ \\
\hline HCM (pcg) & $36.8 \pm 6.2^{\mathrm{a}}$ & $48.2 \pm 4.6^{\mathrm{a}}$ & $31.5 \pm 3.8^{\mathrm{a}}$ \\
\hline CHCM (\%) & $21.4 \pm 0.6^{\mathrm{a}}$ & $24.2 \pm 1.2^{\mathrm{a}}$ & $19.8 \pm 1.9^{a}$ \\
\hline PPT (g/dl) & $4.02 \pm 0.2^{\mathrm{a}}$ & $4.1 \pm 0.8^{\mathrm{a}}$ & $4.7 \pm 0.5^{\mathrm{a}}$ \\
\hline Total leukocytes $\left(\times 10^{3} / \mu \mathrm{L}\right)$ & $28.3 \pm 4.5^{\mathrm{a}}$ & $20 \pm 4.1^{\mathrm{a}}$ & $18.1 \pm 1.4^{\mathrm{a}}$ \\
\hline Lymphocytes $\left(\times 10^{3} / \mu \mathrm{L}\right)$ & $20.3 \pm 3.5^{\mathrm{a}}$ & $13.5 \pm 1.6^{\mathrm{a}}$ & $11.4 \pm 2.7^{\mathrm{a}}$ \\
\hline Neutrophils $\left(\times 10^{3} / \mu \mathrm{L}\right)$ & $3.3 \pm 0.9^{a}$ & $3.6 \pm 0.5^{\mathrm{a}}$ & $4.5 \pm 1.3^{\mathrm{a}}$ \\
\hline Monocytes $\left(\times 10^{3} / \mu \mathrm{L}\right)$ & $1.8 \pm 0.2^{\mathrm{a}}$ & $0.6 \pm 0.2^{b}$ & $0.5 \pm 0.1^{\mathrm{b}}$ \\
\hline Eosinophils $\left(\times 10^{3} / \mu \mathrm{L}\right)$ & $2.5 \pm 0.4^{\mathrm{a}}$ & $1.5 \pm 0.2^{\mathrm{a}}$ & $1.8 \pm 0.3^{\mathrm{a}}$ \\
\hline Basophils $\left(\times 10^{3} / \mu \mathrm{L}\right)$ & $0.2 \pm 0.01^{\mathrm{a}}$ & $0.07 \pm 0.05^{\mathrm{a}}$ & $0.07 \pm 0.03^{a}$ \\
\hline
\end{tabular}

${ }^{1}$ Average $(n=20)$ followed by at least one common letter do not differ in Tukey test $(p>0.05)$.

VG: Corpuscular volume; Ert: erythrocytes, Hb: hemoglobin, MCV: mean corpuscular volume, HCM: mean corpuscular hemoglobin; MCHC: mean corpuscular hemoglobin concentration; PPT: total plasma protein; (BEN) Benzocaine; (EUG) Eugenol and (GGE) guaiacol glyceryl ether.

\section{DISCUSIÓN}

Los tiempos observados para la inducción y recuperación en el grupo BEN fueron inferiores a los encontrados por Delbon y Paiva (19), quienes utilizaron la misma dosis y verificaron tiempos de 1.5 y 4.7 minutos, respectivamente. Esta diferencia puede ser atribuida a la diferencia de la concentración de oxígeno disuelto (OD) en este ensayo en comparación a la medias de $2.3 \mathrm{mg} / \mathrm{L}$ OD observada por los referidos autores. Además, el peso diferente de los peces utilizados en el presente trabajo ya que eran adultos $(100 \pm 12 \mathrm{~g})$ en comparación de los utilizados por Delbon y Paiva (19) que eran alevinos, existiendo correlación de peso con la disminución del tiempo de inducción y recuperación, también verificada en carpas, Cyprinus carpio (20).

\section{DISCUSSION}

The times observed for induction and recovery in the BEN group were lower than those found by Delbon and Paiva (19), who used the same dose and reported times of 1.5 and 4.7 minutes, respectively. This difference can be attributed to the difference in the concentration of dissolved oxygen (DO) in this test compared to the averages of $2.3 \mathrm{mg} / \mathrm{L}$ DO observed by said authors. In addition, the weight of the fish used in this study was different since they were adults $(100 \pm 12 \mathrm{~g})$ compared to those used by Delbon e Paiva (19) which were fingerlings, there being a correlation of weight with the reduction of the induction and recovery time, also verified in carps, Cyprinus carpio (20). 
El tiempo de inducción encontrado para los animales expuestos al eugenol fueron inferiores a los observados en la literatura para juveniles de tilápias del Nilo (19), diferencia que puede ser atribuida a la tasa metabólica, al peso y a la edad (21). El tiempo superior de inducción también fue observado en juveniles de pampo (Trachinotus marginatus), anestesiados con $50 \mathrm{mg} / \mathrm{L}$ de eugenol (22), probablemente debido a la diferencia fisiológica y metabólica entre las especies utilizadas. El tiempo de recuperación para el EUG coincide con los encontrados en tilápias (19).

La inducción a la anestesia profunda debe presentar tiempo corto de latencia (60 a 180 segundos) y la recuperación no debe pasar de 300 segundos (23). En este ensayo, la exposición de tilápia a la benzocaína y al eugenol en la concentración de $100 \mathrm{mg} / \mathrm{L}$ y $50 \mathrm{mg} / \mathrm{L}$ respectivamente. Estos valores corroboran los resultados de trabajos realizados en la misma especie (22).

Los peces anestesiados con EGG presentaron mayores tiempos de inducción y recuperación, debido posiblemente de la farmacocinética del compuesto (24). Los peces anestesiados con EGG no perdieron el equilibrio y la inducción fue confirmada por la manipulación sin reacción. Este comportamiento puede resultar del mecanismo de acción del compuesto, que no es depresor central, pero si miorrelajante (8), lo que posibilitaría el mantenimiento del equilibrio de los peces. No se encontró en la literatura consultada referencias sobre la utilización del éter gliceril guayacolato en peces.

El grado de estrés puede ser estimado a partir de la elevación de los niveles séricos de glucosa, pues la glicemia es una de las respuestas fisiológicas secundarias al estrés, para suplir la mayor demanda energética (25). Los grupos anestesiados con benzocaína y eugenol tuvieron medias de $59.38 \pm 22.98$ y $42.0 \pm 18.71 \mathrm{mg} / \mathrm{dL}$, respectivamente, siendo estadísticamente inferior el grupo EGG $(102.83 \pm 21.45 \mathrm{mg} / \mathrm{dL})$ con relación a los niveles de glicemia determinados.

Los valores de la glicemia obtenidos en los animales anestesiados con benzocaína y eugenol corroboran los encontrados por Tavares - Dias (26) con el uso de benzocaína en O. niloticus. Son considerados valores normales de glicemia aquellos de $57.43 \pm 0.44 \mathrm{mg} / \mathrm{dL}$ (27). Los resultados sugieren que la inducción con EGG no deprime el sistema nervioso central (8) y por eso los peces, están imposibilitados de responder debido al relajamiento muscular, perciben y desencadenan respuestas de estrés a la manipulación y a estímulos dolorosos, evidenciado por el aumento de la tasa de glicemia presentada en los animales tratados con EGG.
The induction time found for animals exposed to eugenol were lower than those observed in the literature for juvenile Nile tilapia (19), a difference that can be attributed to the metabolic rate, weight and age (21). A higher induction time was also observed in juvenile pampo (Trachinotus marginatus), anesthetized with $50 \mathrm{mg} / \mathrm{L}$ of eugenol (22), probably due to physiological and metabolic differences between the species used. The recovery time for EUG coincides with those found for tilapia (19).

The induction and deep anesthesia must have a short latency time (60 to 180 seconds) and recovery should not exceed 300 seconds (23). In this test, tilapia specimens were exposure to benzocaine and eugenol at a concentration of $100 \mathrm{mg} / \mathrm{L}$ and $50 \mathrm{mg} / \mathrm{L}$ respectively. These values confirm the results of studies conducted within the same species (22).

Fish anesthetized with GGE showed higher induction and recovery times, possibly because of the pharmacokinetics of the compound (24). Fish anesthetized with GGE did not lose the balance and the induction was confirmed by manipulation without reaction. This behavior can result from the action mechanism of the compound, which is not a central depressant but a muscle myorelaxant (8), which would enable the maintenance of the balance of the fish. No reference was found in the literature consulted on the use of guaiacolate glyceryl ether in fish.

The level of stress can be estimated from the increase of serum glucose levels, as glycemia is one of the secondary physiological responses to stress, to meet the increased energy demand (25). Groups anesthetized with benzocaine and eugenol showed averages of $59.38 \pm 22.98$ and $42.0 \pm 18.71 \mathrm{mg} / \mathrm{dL}$, respectively, being statistically lower in the GGE group (102.83 $\pm 21.45 \mathrm{mg} / \mathrm{dL})$ in relation to the glycemia levels determined.

Glycemia values obtained in animals anesthetized with benzocaine and eugenol corroborate those found by Tavares - Dias (26) with the use of benzocaine in O. niloticus. Normal glycemia values are considered as $57.43 \pm 0.44 \mathrm{mg} / \mathrm{dL}$ (27). The results suggest that induction with GGE does not depress the central nervous system (8) and therefore fish are unable to respond due to muscle relaxation, perceive and trigger stress responses to handling and painful stimuli, evidenced by the increase in the glycemia rate shown by animals treated with GGE. 
Las variables hematológicas de las especies de peces son de interés ecológico, fisiológico y patológico. Estos análisis auxilian en la comprensión de la relación entre las características sanguíneas y el ambiente (28). Los resultados del hemograma y de la concentración de proteínas totales de los animales sometidos a la anestesia con todos los compuestos ensayados, no presentaron diferencias significativas, corroborando los valores encontrados en tilápias anestesiadas con benzocaína y eugenol en diferentes concentraciones (29). En tambaquis (Colossoma macropomum) anestesiados con eugenol no se verificaron alteraciones en las variables sanguíneas, excepto por el aumento en el hematocrito. Los autores atribuyeron este hecho a la mayor hidratación de los glóbulos rojos frente al estímulo estresante a que los animales fueron expuestos (30), hecho que no fue observado en el presente ensayo.

Una posible explicación para el aumento del número de monocitos observada en el grupo BEN puede ser atribuida a que la benzocaína posee propiedades irritantes como el ácido p-aminobenzóico, dejando los peces agitados durante el inicio del ensayo y como consecuencia la movilización del pool marginal de los monocitos y aumento del mismo en la circulación. Esta alteración comportamental en el inicio del proceso de inducción, también fue observada por Delbon (29).

Los resultados del presente estudio permiten concluir que los anestésicos no causaron alteraciones hematológicas. La benzocaína ( $100 \mathrm{mg} / \mathrm{L}$ ) y el eugenol $(50 \mathrm{mg} / \mathrm{L})$ permitieron rápida inducción y recuperación en tilápias del Nilo sin evidencias de estrés durante la manipulación. El éter gliceril guayacolato en la concentración testada (900 mg/L), así haya inducido la anestesia de los peces, presentó un tiempo elevado de inducción y recuperación, y se mostró inadecuado para el uso en $O$. niloticus.
The hematologic variables of fish have an ecological, physiological and pathological interest. These analyses help to understand of the relationship between blood characteristics and the environment (28). The results of the hemogram and total protein concentration in animals subjected to anesthesia with all the compounds tested, did not show significant differences, corroborating the values found in tilapia anesthetized with benzocaine and eugenol in different concentrations (29). In tambaquis (Colossoma macropomum) anesthetized with eugenol, no alterations in blood variables were verified, except for the increase in hematocrits. The authors attributed this fact to the higher hydration of red blood cells due to the stressful stimulus to which animals were exposed (30), a fact not observed in this test.

A possible explanation for the increase in the number of monocytes observed in group BEN can be attributed to the fact that benzocaine has irritative properties such as $\mathrm{p}$-aminobenzoic acid, leaving the fish agitated during the start of the test and as a result the mobilization of the marginal pool of monocytes and the increase of the same in blood circulation. This behavioral alteration in the beginning of the induction process was also observed by Delbon (29).

The results of this study suggest that the anesthetics did not cause hematological alterations. Benzocaine $(100 \mathrm{mg} / \mathrm{L})$ and eugenol $(50 \mathrm{mg} / \mathrm{L})$ enabled a rapid induction and recovery in Nile tilapia without evidence of stress during handling. The guaiacolate glyceryl ether in the concentration tested $(900 \mathrm{mg} / \mathrm{L})$, despite having induced the anesthesia of the fish, showed a high induction and recovery time and was inappropriate for use in $O$. niloticus.

\section{REFERENCES}

1. Belo MAA, Moraes JRE, Soares VE, Maritns $M L$, Brum CD, Moraes FR. Vitamin C and endogenous cortisol in foreign-body inflammatory response in pacus. PAB 2012; 47:1015.

2. Hasan M, Bart AN. Improved survival of rohu, Labeo rohita (Hamilton-Buchanan) and silver carp, Hypophthalmichthys molitrix (Valenciennes) fingerlings using low-dose quinaldine and benzocaine during transport. Aquac Res 2007; 38:50-58.
3. Holloway AC, Keene JL, Noakes DG, Moccia RD. Effects of clove oil and MS-222 on blood hormone profiles in rainbow trout Oncorhynchus mykiss. Aquac Res 2004; 35:1025-1030.

4. Davis KB, Griffin BR. Physiological responses of hybrid striped bass under sedation by several anesthetics. Aquacult 2004; 233:531-548. 
5. Mazzafera P. Efeito alelopático do extrato alcoólico do cravo-da-índia e eugenol. Rev Bras Bot 2003; 26:231-238.

6. Wagner E, Arndt R, Hilton B. Physiological stress responses, egg survival and sperm motility for rainbow trout broodstock anaesthetized with clove oil, tricaine methanesulfonate or carbon dioxide. Aquaculture 2002; 211:353-366.

7. Kildea MA, Allan GL, Hearney RE. Accumulation and clearance of the anesthetics clove oil and AQUI-S ${ }^{\mathrm{TM}}$ from the edible tissue of silver perch (Bidyanus bidyanus). Aquaculture 2004; 232:265-277.

8. Andrade, SF. Manual de Terapêutica Veterinária. $3^{a}$ ed. Brasil: Roca São Paulo; 2002.

9. Roubach R, Gomes LC, Fonseca FAL, Val $A L$. Eugenol as an effi cacious anaesthetic for tambaqui, Colossoma macropomum (Cuvier). Aquac Res 2005; 36:1056-1061.

10. Gomes LC, Chippari-Gomes AR, Lopes NP, Roubach R, Araujo-Lima CARM. Efficacy of benzocaine as an anesthetic in juvenile tambaqui Colossoma macropomum. J World Aquacult Soc 2001; 32:426-431.

11. Ross LG, Ross B. Anaesthetic and Sedative techniques for Aquatic Animals. 2a ed. London: Willey-Blackwell Publishing; 2008.

12. Lourenço KG, Claudiano GS, Eto SF, Aguinaga JY, Marcusso PF, Salvador R, et al. Hemoparasite and hematological parameters in Nile tilapia. Comp Clin Path 2012; DOI: $10.1007 /$ s00580-012-1638-8.

13. Madella DA, Neto EJR, Felisberto ME, Souza CE. Valores hematológicos de capivaras (Hydrochoerus hydrochaeris) de vida livre na região de Campinas-SP. Cienc Rural 2006; 36:1321-1324.

14. Martins ML, Pilarsky F, Onaka EM, Nomura DT, Fenerick JR. J, Ribeiro K, Myiazaki DMY, Castro MP et al. Hematologia e resposta inflamatória aguda em Oreochromis niloticus (Osteichthyes: Cichlidae) submetida aos estímulos único e consecutivo de estresse de captura. Bol Inst Pesca 2004; 30:71-80.

15. Tavares-Dias M, Moraes FR. Haematological and biochemical reference intervals for farmed channel catfish. J Fish Biol 2007; $71: 383-388$.
16. Grush J, Noakes DLG, Moccia RD. The effi cacy of clove oil as an anesthetic for the zebrafi sh, Danio rerio (Hamilton). Zebrafish 2004; 1:46-53.

17. Correa, SMBB. Probabilidade e estatítica. $2^{a}$ ed. Belo Horizonte, Brasil: PUC Minas Virtual; 2003.

18. Santos DMS, Cruz CF, Pereira DP, Alves LMC, Moraes FR. Microbiological water quality and gill histopathology of fish from fish farming in Itapecuru-Mirim County, Maranhão State. Acta sci Biol sci 2012; 34:199-205.

19. Delbon MCE, Paiva MJTR. Eugenol em juvenis de tilápia do Nilo: concentrações e administrações sucessivas. Bol Inst Pesca 2012; 38:43-52.

20. Antunes MIPP, Spurio RS, Godoi DA, Grumadas CES, Rocha MA. Cloridrato de benzocaína na anestesia de carpas (Cyprinius carpio). Semina Cienc Agrar 2008; 29:151-156.

21. Gilman AG. The Pharmacological Basis of Therapeutics. 6a ed. Rio de Janeiro, Brasil: Guanabara-Koogan; 2010.

22. Okamoto MH, Tesser MB, Louzada LR, Santos RA, Sampaio LA. Benzocaína e eugenol como anestésicos para juvenis do pampo Trachinotus marginatus. Cienc Rural 2009; 39:866-870.

23. ROSS LG, ROSS, B. Anesthesia, sedation and transportation of juvenile Menidia estor (Jordan) using benzocaine and hypothermia. Aquacult Res 2007; 38:909-917.

24. Smith J, Colon J, Madero-Visbal R, Isley B, Konduri DS, Baker HC, Davis LE, Wolff WA. Blockade of MUC1 Expression by Glycerol Guaiacolate Inhibits Proliferation of Human Breast Cancer Cells. Anticancer Agents Med Chem 2010, 10:644-650.

25. Martins ML, Miyazaki DM, Moraes FR, Giraldelli L, Adamante WB, Mouriño JLP. Ração suplementada com vitraminas C e E influencia a respostas inflamatoria aguda em tilápia do Nilo. Cienc Rural 2008; 38:213-218.

26. Tavares-Dias M, Moraes FR. Hematological parameteres in two neotropical freswater teleost, Leporinus macrocephalus (Anostomidae) and Prochilodus lineatus (Prochilodontidae). Biosci J 2008; 24:96-101. 
27. Tavares-Dias M. Manejo e Sanidade de Peixes em Cultivo. $1^{\text {aed. }}$. Brasil: Embrapa Amapá, Amapá; 2009.

28. Tavares-Dias M, Moraes FR, Schalch SHC. Hematological characteristics of brazilian teleosts. VII. Parameters of seven species collected in Guariba, São Paulo State, Brazil; Bol Inst Pesca 2003; 29:109-115.
29. Delbon MC. Ação da Benzocaína e do Óleo de Cravo sobre parâmetros fisiológicos de tilápia, Oreochromis niloticus, [Tesis Doctoral]. Jaboticabal, Brasil: Universidade Estadual Paulista. Centro de Aquicultura: 2006.

30. Inoue LAKA, Boijink CL, Ribeiro PT, Silva AMD, Affonso EG. Avaliação de respostas metabólicas do tambaqui exposto ao eugenol em banhos anestésicos. Acta Amaz $2011 ; 41: 327-332$. 